\title{
Imagen impersonal y ninfa posthumana. Lecturas "nietzscheanas" de Warburg
}

Recibido el 1 de mayo de 2019: aceptado el 3 de julio de 2019

\begin{abstract}
Resumen
Este trabajo analiza tres interpretaciones del pensamiento de Warburg que buscan volver a pensar los elementos que los discípulos inmediatos de Warburg debieron dejar de lado para construir una iconología como "ciencia humanista": la "vida" en el concepto de Nachleben, el "pathos" en el de Pathosformel y una cierta interpretación de la ninfa como devenir inhumano del cuerpo femenino. Es decir, por un lado, se estudian los planteos agambenianos en torno al carácter polar, no dicotómico, de las fórmulas del pathos y su relación con la vida póstuma (simultáneamente fisiológica e histórica) de las imágenes; lo que permitiría pensar el arte como un modo de hacer que conserva y transforma el espacio a-subjetivo de las emociones en una experiencia de lo impersonal. Por otro lado, se examinan las consideraciones didi-hubermanianas en torno al modo de existencia (Lebensformen) involucrado en la supervivencia de las imágenes, entendido como un juego impuro de latencias y violencias, alejado de la estética moderna del gusto. Y, finalmente, a partir de la lectura de Paskaleva, se busca pensar la figura de la ninfa por fuera de su reducción a un objeto de deseo masculino como esquema de una expresión de afectividad ya no humana.
\end{abstract}

\section{Impersonal image and post-human nymph. Warburg's "Nietzs- chean" readings}

\begin{abstract}
This paper analyzes three interpretations of Warburghian thought that seek to re-think the elements that the immediate disciples of Warburg put aside in order to build an Iconology as a "Humanistic Science": "Life" in the concept of "Nachleben", "Pathos" in the concept of "Pathosformel" and an interpretation of the nymph as an inhuman becoming of the female body. Firstly, it studies the Agambenian suggestions around the non-dichotomous but polar character of pathos formula and its relationship with the images survival. This allows to think Art as a "way of making" that preserves and transforms the non-subjective space of emotions
\end{abstract}

Palabras clave Warburg Ninfa Impersonal Posthumano

Keywords

Warburg Nimpha Impersonal Posthuman 
1. No me ocuparé aquí de ello, pero una interpretación que devuelve el estatus filosófico central (y con ello político) del problema de la locura en Warburg, puede leerse en Ludueña Romandini, 2017. Alli leemos: “Warburg había transformado a la locura misma en la matriz metodológica que organiza la totalidad de su trabajo de investigación" (21). Por lo demás, la dimensión extra-humana en la que Ludueña busca situar el pensamiento de Warburg es el punto de partida de este trabajo. into an impersonal experience. Secondly, the article examines Didi-Huberman's considerations on the modes of existence (Lebensformen) involved in the survival of images, which is understood as an impure game of latencies and violence, far away from the Modern Aesthetics of taste. And, finally, through the reading of Paskaleva, we think the figure of the nymph not as an object of male desire but rather as an expression of a no-longer- human affectivity.

\section{Warburg, Nietzsche y la incertidumbre fundamental}

La obra de Aby Warburg parece haber logrado con sus lectores lo que Nietzsche pedía a los suyos: que cada uno rehiciera sus textos a imagen y semejanza propia, en función de las propias obsesiones (Nietzsche, 1994a: 57). En términos muy generales, podría decirse que hubo inicialmente una tradición de lectura vinculada con sus herederos directos que logró hacer de él tanto el padre de un método iconológico que habilita el uso de testimonios figurativos como fuentes históricas legítimas (Ginsburg), como el precursor de un método indiciario para el estudio histórico de las imágenes artísticas (Panofsky/Gombrich). Y es que, tras la muerte repentina de Warburg en 1929 y el desencadenamiento de los sucesos mundiales que llevaron a la migración de su Biblioteca desde Hamburgo a Londres, la disolución de los elementos más revulsivos, "irracionales" y experimentales de su obra parece haberse hecho necesaria para su "traducción" al nuevo medio académico que la albergaba.

Por ello, quizás, es la cuestión metodológica, a la vez novedosa y tranquilizadora, la que se afirma como central para esta interpretación iconológica, que, a cambio, resigna (además de las suculentas cuestiones anímico-biográficas) ${ }^{1}$ las implicancias filosóficas más difíciles de evaluar: Saxl, por ejemplo, habla de "un ferviente deseo de simplificación filosófica" opuesta a, y en tensión con, una vasta "imaginación histórica" (en Ginsburg, 2013: 60). Sin que sea posible concluir que hay en Warburg algo así como un sistema filosófico, una teoría de las imágenes acabada o una Kunstwissenchaft, como argumentaba Edgard Wind al defenderlo de sus detractores en 1930, una siguiente generación de estudiosos ha querido pensar las resonancias filosóficas involucradas en estos ensayos de pensamiento donde la palabra no es ciertamente el elemento organizador determinante, pero en los que se esbozan una serie de ideas que repercuten acaso en nuestra agenda filosófica más actual.

Dentro de nuestro ámbito local, en Historia, Arte, cultura. De Aby Warburg a Carlo Ginsburg, Burucúa constata la existencia de lo que llama "abordajes en términos nietzscheanos de la labor warburguiana" (Burucúa, 2003: 11) que más tarde describirá como interpretaciones en clave antropológica tributarias de la filosofía postestructuralista y del psicoanálisis, entre las cuales menciona la de Giorgio Agamben y la de Georges Didi-Huberman. Confesadamente cerca de la lectura más iluminista y popperiana de Gombrich, Burucúa no sólo relativiza la importancia que pudo haber tenido Nietzsche en el pensamiento warburguiano (Gombrich habla de un vaivén del interés y de un progresivo alejamiento con respecto al filósofo de la tragedia) sino que parece asociar dichas "interpretaciones nietzscheanas" con una mirada que busca en el concepto de Pathosformel una constante universal (eterna o más allá de la historia) en el contexto del descubrimiento por parte del hombre de "su lugar perenne frente al mundo", mirada, por lo demás, incompatible con una lectura histórica culturalmente situada como la que él expone (Burucúa, 2011: 42). La propuesta de Burucúa es coherente con el problema que lo guía, más allá de la perplejidad que pueda producirnos la identificación del nietzscheanismo con la idea de una universalidad fuera de la historia, dado que el de Nietzsche es un pensamiento de los comienzos -incluso su primer libro, tildado por él mismo de hedionda metafísica hegeliana, lleva por título la palabra Geburt-, históricos y humanos en el sentido de inventados o construidos, y no de las 
eternidades universales. O, para decirlo con Foucault, dado que su genealogía se opone precisamente al despliegue "meta-histórico de las significaciones ideales y de las indefinidas teleologías" (Foucault, 2004: 13).

La propuesta de Burucúa, decía, es coherente con el problema que lo guía: si lo que se pretende es fundamentar en la obra de Warburg una teoría general de la cultura (un sistema de explicación histórica o antropológica sostenido en dos principios básicos: el Denkraum y la Pathosformel), es imprescindible si no liberarlo del lastre de la influencia siempre caótica de Nietzsche y el nietzscheanismo, al menos limitarla a la constatación del fenómeno del dionisismo en la antigüedad clásica. Después de todo, Nietzsche es el filósofo de la imposibilidad de los sistemas y de la sospecha sobre el humanismo, un fantasma loco que pone en riesgo la empresa de construir un suelo seguro para la historia del arte.

Para decirlo brevemente, lejos de una circunspecta disciplina académica, Nietzsche concibe su tarea filosófica como un agón, una lucha contra las enfermedades de Occidente y, por lo tanto, como una medicina frente a ella. ${ }^{2}$ Sufre, como un enfermo en recuperación, de una aversión a los sistemas filosóficos que ubican sus conceptos en torno a un centro fundante (Nietzsche, 1994: 51-52) y que anhelan un más allá ideal que los justifique (Nietzsche, 1999: 3). La concepción trágica de la existencia, la crítica a la metafísica y al concepto de subjetividad moderno, son acaso las constantes mejor diseminadas en toda su obra y constituyen el ineludible punto de partida para una comprensión no sólo de la crítica a lo que Warburg por su parte llamará "la historia del arte estetizante" (2017: 213) sino también de la propuesta estética del último Nietzsche, conocida como "fisiología del arte", que implica entre otras cosas un desfasaje respecto de la centralidad del sujeto como fundamento de la modernidad filosófica [F. Nietzsche, $N F$ 1885, 35 [35], KSA 11, p. 526] que dio origen a la Estética como disciplina autónoma. $Y$ es que Nietzsche mismo es, para retomar la caracterización warburguiana, un sismógrafo, "un captador de la onda mnémica" que tiembla al recibirla; un "vidente" que hace causa común con el demonio (Warburg, 1971: 46-48), es decir, con "el lugar donde el cosmos se torna la experiencia más próxima de Homo" (Ludueña 2017: 59) y amenaza con disolverlo en una emotividad inhumana. No un yo que piensa y que al hacerlo otorga cierta cognoscibilidad al mundo del devenir, sino una construcción del pensar impersonal (Nietzsche, NF 188535 [35]), que es pensado y gobernado por todas las cosas del mundo, como enuncia von Hofmannsthal a propósito del poeta (cfr. Michaud, 2017:256).

Se comprenderá, entonces, quizás, por qué si se busca ubicarlo en la fundación misma de una teoría de la cultura o de una disciplina iconológica, conviene alejar a Warburg de Nietzsche. ${ }^{3}$

Contrariamente, la "obsesión" que guía el presente trabajo es la de la existencia de un pensamiento materialista de la imagen que excede por desborde los planteos de la iconología como "ciencia humanista" que propusiera Panofsky (1987: 17-41), pero que parece estar presente en la dispersión de algunas formulaciones warburguianas retomadas luego por algunos de sus comentadores. Una concepción de la imagen que no se circunscriba a la cuestión de la mirada, el retrato o su estructura (cfr. por ejemplo J.-L. Nancy, 2007), sino que la piensa en su a-subjetividad, su materialidad y su espacialidad, en su confusión y oscuridad. Ni representación (visible) de un real que le sirve de modelo, ni símbolo abstracto (invisible) encargado de suturar la inestable relación entre lo que hay y el pensamiento humano (cfr. Melandri, 2004) en favor de una dominación de la contingencia de lo existente, la imagen es material o encarnada, e invierte quizás aquella relación de dominio: ella se apodera de nosotros, ante ella nos dejamos desposeer en el saber sobre ella (Didi-Huberman, 2009). En Ante el tiempo, Didi-Huberman se propone reconstruir
2. Otro punto de contacto con Warburg, que hace de su obsesión "patológica" el objeto científico de una ciencia de la expresión de los afectos. Cfr. Paskaleva, 2016: 34 y Didi-Huberman, 2017: 22.
3. Por supuesto numerosos estudiosos han trabajado ya esta relación (Cfr. Michaud, 2017, Didi-Huberman, 2017 y 2009b), pero como señala Ghelardi en una entrevista a propósito de la edición italiana del tomo Il de las obras de Warburg, parece que nadie aún ha indagado a fondo la lectura que Warburg hizo de $E$ I nacimiento de la tragedia y de qué modo ha "metabolizado algunos aspectos fundamentales de las reflexiones del filósofo alemán sobre la civilización griega de los orígenes y, sobre todo, en relación al motivo por el cual Nietzsche definió su escrito como una contribución a la estética" (Ghelardi, 2008: 23). 
4. Aunque desde una perspectiva diferente a la aquí propuesta, S. Papapetros (2016) ofrece una muy interesante lectura de la relación del pensamiento warburguiano con los nuevos materialismos. Analizando unos dibujos de "Fragmentos sobre la expresión", llama la atención sobre la relación polar que Warburg propone entre sujeto y objeto que implica a la vez una máxima intimidad entre ambos en el mutuo contacto físico dentro del ambiente material en el que están emplazados y una concepción de la agencialidad que no queda fijada en ninguno de los dos polos sino que es constantemente transferida de uno a otro. (Cfr. Papapetros, 2016: 76-78)

5. Ecce homo puede ser leído como un libro pionero en este tipo de intervención singular-impersonal (Nietzsche, 1994a). una cierta tradición materialista de la imagen que quedó trunca frente a la tiranía del significado y que ha pensado su presentabilidad desde el desgarro constitutivo de todo conocimiento, desgarro que nombra con el término freudiano de síntoma. Es a esta tradición materialista que piensa la imagen como un síntoma a la que intentaré contribuir aquí, esa tradición que encuentra en las imágenes un movimiento de cuerpos desprovisto de voluntad, ${ }^{4}$ pero considerando el síntoma en su aspecto etimológico, sin un sustrato subjetivo en el que emplazarse: un tipo de contigüidad fortuita que no envía a un más allá ideal sino que entrevera un más acá material en el que las cosas vienen a caer juntas, una al lado de la otra (cfr. Vidarte, 2006); una "señal de que algo está sucediendo o está por suceder", según reza la segunda definición del Diccionario de la Real Académica Española; o también, por qué no, la sugerencia de un advenimiento soplado a través de accesorios en movimiento (bewegtes Beiwerk).

Por ello, tomando como hilo conductor la indicación de Burucúa, analizaré algunos elementos de los "abordajes nietzscheanos" que intentan no acallar esa "incertidumbre fundamental" a la que se está expuesto toda vez que se aborde a un autor que "asume que es la propia psique la materia impersonal con la que debe trabajar" (Didi-Huberman, 2011: 32). Subrayando, además, que la "propia psique" no es pensada como el centro de imputaciones racionales o irracionales de un sujeto sino como una "materia impersonal" con la que, como lo supo Nietzsche, 5 todo pensador debe medirse.

Aunque el eje privilegiado de análisis de la obra warburguiana sea en Agamben y en Didi-Huberman el estudio de fenómenos humanos, en ninguno de los dos la figura humana será la piedra de toque fundamental a partir de la cual justificar una ciencia que se ocupe de los significados como testimonios inmateriales de la dignidad de la obra humana. O bien se piensa el punto mismo en el que biología e historia se encuentran y revelan el carácter construido de lo humano, o bien una afectividad a-subjetiva que desborda lo humano (lo viviente en general), y con ello, en algún sentido, se hace de Warburg uno de los precursores de los debates filosóficos posthumanistas que objetan la mirada antropocentrada sobre el fenómeno de la obra de arte. Lejos de ser el padre de una disciplina humanista, Warburg podría ser, entonces, el pensador de la transformación de la emotividad impersonal (lo patético no es la expresión del genio artístico) en la materia de las imágenes artísticas, o, según la fórmula de Ludueña, el creador de una "ciencia de lo viviente en cuanto ser sensitivo" (2009: 19).

De esta manera, Agamben y Didi-Huberman parecen haber abierto el campo de los estudios warburguianos a un cierto posthumanismo implicado tanto con las lecturas de la "biología de las imágenes" que Warburg defiende frente a la estetizante "contemplación formal de la imagen" (Severi, 2003), como con aquellas que permiten encontrar en la ninfa una Pathosformel inhumana (Paskaleva, 2016), a cuyo análisis dedicaré la última parte de este trabajo. En efecto, si los conceptos de Nachleben (vida póstuma o supervivencia) y Pathosformel (fórmula del pathos) son pensados desde una perspectiva (¿nietzscheana?) que los asuma en su hibridez y en su materialidad, la vida y el pathos en ellos implicados no pueden ser "exorcizados" con los conceptos iconológicos de "influencia", "herencia" o "tipificación" (Didi-Huberman, 2009b: 81-91). Por ello, y a modo de exploración de los posibles antecedentes de un pensamiento materialista posthumano de la imagen, estudiaré en primer lugar la interpretación agambeniana de las fórmulas del pathos, luego las consideraciones de Didi-Huberman en torno a la supervivencia y, finalmente, la lectura de la ninfa como figura de lo inhumano que excede el círculo ant(d)rópico que busca circunscribirla a la fantasía masculina elemental del perfecto objeto de deseo. 


\section{La lectura agambeniana: de la "ciencia general de lo hu- mano" al estatuto impersonal de la imagen}

En "Aby Warburg e la scienza senza nome" (1975), Agamben presenta el proyecto warburguiano como un intento de ir más allá de la estética formalista. El concepto de Pathosformel no es una reivindicación de la forma o del significado, ni puede ser reducido al mero "tema primario" de una imagen, ${ }^{6}$ sino que implica una indistinción entre forma y contenido: designa, dice Agamben, la "indisoluble imbricación de una carga emotiva y de una fórmula iconográfica" (Agamben, 2005: 125). Las fórmulas del pathos son el repertorio gestual de las cristalizaciones de las experiencias polares producidas por una serie de huellas de estímulos externos impresos en la psique (que Warburg, con Richard Semon, llama "engramas"), huellas que producen respuestas automatizadas ante la aparición de esos mismos estímulos. Experiencias polares y carga emotiva, es claro que no es en busca de categorías historiográficas ni iconológicas que Agamben lee a Warburg (incluso aunque lo haga desde la lectura de Gombrich) sino a partir de una preocupación filosófica por los procesos de polarización que atraviesan la cultura occidental y que no son superados ni superables dialécticamente.

De esta manera, las fórmulas del pathos, esos mecanismos sensibles a través de los cuales las formas artísticas objetivan los engramas y suscitan el recuerdo de experiencias emotivas primitivas (Burucúa, 2003: 28-29), no funcionan de modo dicotómico como en el modelo estético formalista, es decir, no son las formas ideales disponibles que el genio artístico imprime en una materia inerte para fruición de un espectador desinteresado. Las Pathosformeln son una existencia híbrida que consiste en la simultaneidad de creación y performance, de materia y forma, de primera vez y repetición (Agamben, 2008: 31 y Agamben, 2004b: 55-56), de significación y afectividad; son, de este modo, una mezcla imposible de pasión y forma establecida: singularidad y estereotipo, un "indecidible de diacronía y sincronía". Es con este lenguaje gestual patético, estereotipado y repetitivo, que se mide el artista "para dar expresión a la vida en movimiento", dirá Agamben en Ninfas (2004b: 55).

Agamben parece haber comprendido rápidamente el alcance del "disgusto" warburguiano con la historia del arte estetizante que en su contemplación formal de la imagen no lograba considerarla como "un producto biológicamente necesario entre la religión y la práctica artística" (citado en Severini, 2003: 86 y en Agamben, 2005: 127). Como ya había afirmado Wind "[u]na de las convicciones básicas de Warburg era que cualquier intento de separar la imagen de la religión o de la poesía, del culto o del drama, es como privarla de su linfa vital" (Wind, 1993: 68). De esta manera, eso que sobre-vive, esa linfa vital de las imágenes no son los temas o los estilos personales sino las fórmulas patéticas que se conservan y se transforman en una memoria no consciente que comparten todos los seres vivos (Semon habla de la memoria como "la cualidad que distingue al viviente de la materia inorgánica"). Lo que sobrevive en las fórmulas de lo patético es un tipo de vida impersonal: el de las emociones que son el umbral de la individuación (Agamben, 2005b: 4). La Pathosformel, dirá Agamben más tarde a propósito de la ninfa, "no es la materia pasional a la que el artista debe conferir nueva forma, ni un molde para ajustar a él los propios materiales emocionales" (Agamben, 2004b: 56), de modo tal que la prerrogativa del arte parece ser la conservación y la transformación de esa energía fisiológica, es decir, de las emociones que son la experiencia misma de lo impersonal. Consecuentemente, el proyecto de pensar en Warburg una "ciencia general de lo humano" se transforma, ya en la apostilla que Agamben escribe en 1983 al texto de 1975, en el de la consideración del "estatuto de la imagen". Pues la imagen, dirá a propósito de la pintura de Savinio Rugieri, es en nuestra cultura la designación de un imposible: el lugar donde la metafísica occidental ha buscado la solución de su enigma más propiamente central,

6. Los especialistas suelen situar la "explicitación" del concepto de Pathosformel en este artículo de 1905 , donde Warburg reconduce el motivo, tanático y erótico a la vez, de la muerte de Orfeo por manos de sus amantes, en un dibujo de Durero de 1494 y en su modelo —un grabado en cobre anónimo de Italia septentrional一, al lenguaje gestual patético del arte antiguo. Dice Warburg allí: "El típico lenguaje mimético patético del arte antiguo, tal como Grecia lo había elaborado para esta escena trágica, incide aquí determinando directamente el estilo". Inmediatamente después, enumerando una serie de obras muy diferentes que representan la "muerte de Orfeo", Warburg afirma que todas ellas "muestran [...] con tanta fuerza vital esta misma fórmula patética, arqueológicamente fiel (archäologisch getreue Pathosformel), inspirada en una representación de Orfeo o de Penteo" (Warburg, 1996: 195-196). 
la unión de lo sensible y de lo inteligible, de lo múltiple y lo uno (Agamben, 2004: 139). De esta manera, el arte trata con el gran problema filosófico de la imagen, que más adelante será pensada por Agamben, a partir del paradigma de la autoafección y la autorreferencialidad, como potencia que une en sí pasividad y espontaneidad, y que desbarata el orden impuesto por las dicotomías metafísicas, convirtiéndolas en polos en tensión dentro de un campo de fuerza. Potencia que, cuando Agamben comience su trabajo de diagnóstico político de Occidente, será también el concepto elegido para pensar lo viviente (Agamben, 2005: 286).

En Nimphae (2004), el filósofo italiano se ocupa del tópico del amor a la imagen, como ya había hecho en Stanze, a través de una lectura de la cifra misma de toda Pathosformel, la ninfa: esta "figura femenina en movimiento, con las ropas agitadas", que aparece como tópico en los artistas del Quattrocento y que es explicada por Warburg como un Nachleben derAntike, ya en su tesis sobre el "Nacimiento de Venus" y la "Primavera" de Sandro Botticelli (1893). Se trata de una Pathosformel clásica, conservada en las paredes de los sarcófagos antiguos, con la que los artistas renacentistas evocan la vitalidad pagana, latente en textos e imágenes antiguos pero olvidados en los siglos de cristianismo medieval. Agamben afirma que la "ninfa" warburguiana no es ni un objeto externo ni un ente intrapsíquico, sino la figura más límpida del propio sujeto histórico, una supervivencia encarnada: ella asume "la ambigua herencia de la imagen", esa encrucijada entre corpóreo e incorpóreo, pero también y sobre todo, entre lo individual y lo colectivo. Por ello, como en la fantasmología averroísta que sobrevive en la teoría del amor stilnovista -donde el conocimiento es un reflejarse de fantasmas como en un espejo y la imaginación es la copulatio entre fantasma e intelecto único y separado- las imágenes que Warburg colecciona se sitúan en el límite entre individual y universal, y constituyen, a la vez, la consistencia de lo humano y el lugar del incesante faltarse a sí mismo de lo humano (Agamben, 2004b: 66).

\section{Didi-Huberman y la supervivencia de las imágenes}

La arqueología crítica de la historia del arte emprendida por Didi-Huberman toma como punto de partida el necesario alejamiento de la perspectiva humanista panofskiana, heredera de Vasari y Kant. Dice en Ante la imagen (2009: 19): "la historia del arte [moderna, como disciplina] quiso enterrar las muy viejas problemáticas de lo visual y lo figurable dando nuevos fines a las imágenes del arte, fines que colocaban lo visual bajo la tiranía de lo visible (y de la imitación), lo figurable bajo la tiranía de lo legible (y de la iconología)".

Se trata de entender lo visual, intraducible al lenguaje del sujeto, como materia que si bien pertenece al mundo de la representación, la intensifica fuera de sus límites, desplegando otra cosa. Ni visible (representación), ni invisible (abstracto), la imagen es visual, tangible, encarnada y por ello será el bajo materialismo de Georges Bataille una de las referencias ineludibles para deconstruir el sintagma "historia del arte" 7 y encontrar una sobredeterminación tanto del objeto (imagen/obra de arte/montaje) como del modo en que se lo aborda (historia/anacronismo/heterocronicidad).

Entre los miembros eminentes de aquella tradición subterránea que quedó trunca tras la persecución nazi de los judíos en la segunda querra mundial, el estudioso francés ubica a Warburg, a quien le dedica además un libro aparte, La imagen superviviente (2002). Allí, Didi-Huberman propone tomar en serio la importancia "vital" que Warburg otorgaba al arte, y pensar, precisamente, el modo de existencia (Lebensformen) involucrado en la supervivencia de las imágenes. 
Reconstruyendo la importancia de Nietzsche en el planteo warburguiano, ${ }^{8}$ sugiere Didi-Huberman que contra una estética del gusto, la obra de arte renacentista es pensada como una fuerza vital, como un "organismo dotado de energía vital", y lo que sobrevive en ella es la polaridad entre el ethos apolíneo y el pathos dionisíaco inherente, por lo demás, a la tragedia de la cultura. La obra de arte, desde esta mirada, no puede ser considerada como un objeto de conocimiento o de fruición desinteresada, sino que Warburg nos da a entender que "ante cada obra nos vemos concernidos, implicados en algo que no es exactamente una cosa sino más bien -y en este punto Warburg hablaba como Nietzsche- una fuerza vital que no podemos reducir a sus elementos objetivos" (Didi-Huberman, 2009b: 129).

En las numerosas páginas que Didi-Huberman dedica a la recepción warburguiana de Nietzsche y de Burckhardt, vemos construirse una interpretación del problema del Nachleben de las imágenes que enfatiza la segunda de las palabras que componen el concepto: Leben. La intención de Warburg, nos dice, era la de comprender la "vida", la "fuerza" o "potencia" (Kraft, Macht) impersonal que sobrevive en las imágenes. Pero esta vida es la vida de una cultura, una vida que, aunque conserva plenamente su carácter natural - la emotividad primordial- es también una vida histórica, no natural. De esta manera, el problema de la transmisión de lo antiguo que Warburg intenta reconstruir alejándose del concepto de imitación winckelmanniano, implica una idea de Lebensenergie, fuerza o reflujo que sobrevive en el arte. El Nachleben des Heidentums en el arte del Renacimiento es entonces la supervivencia, entendida como una vida continuada en este mundo, del carácter polar y exuberante de la vida cultural antigua: una belleza a la vez superficial y terrible, humana y animal, que combate sin reconciliación duradera dentro de la imagen. La humanidad cristiana, como ya lo había alertado Nietzsche, "estará atravesada por una energía pagana cuyas supervivencias fueron precisamente el objeto de toda la investigación de Warburg" (DidiHuberman, 2009b: 137)..$^{9}$ Las fórmulas antiguas, reapropiadas y cambiadas, sobreviven en la memoria inconsciente, material, transmitida "en la carne y en la sangre", pues es ella misma la carne de las cosas, el material plástico del que están hechas las imágenes.

\section{De la imagen impersonal hacia una interpretación posthumana de la ninfa}

En las dos interpretaciones hasta aquí analizadas, la de Agamben y la de Didi-Huberman, pervive, por supuesto, un cierto amarre en lo humano: la imagen es para Agamben el principio definitorio de la especie humana, y Didi-Huberman sostiene su lectura en una convergencia teórica con el concepto freudiano de "síntoma", anclado en la psique humana. No obstante, al pensar la concepción warburguiana de las imágenes, ninguno de ellos intenta fortalecer la constitución de la "persona" (el aspecto subjetivo e individual de Homo), sino que al contrario, ambos buscan dar cuenta del carácter impersonal y pre-individuado involucrado en los conceptos de Pathosformel y de Nachleben. Así, leído a partir de la influencia de Burckhardt y de Nietzsche, Warburg reivindicaría en su lectura del arte del Renacimiento, una "vida póstuma", a la vez natural (sensorial, emotiva) e histórica (cultural) de las imágenes, que implica la concepción de la "vida" como "fuerza" o "potencia" impersonal directamente relacionada con el "hacer" del arte. La "vida de las imágenes" sería una especie de producto híbrido entre naturaleza y cultura que nos ofrece una posible relación entre arte y vida no sostenida ni en una metafísica de la subjetividad ni en una del impulso vital.

En lo que sigue, y para concluir, quisiera detenerme en una interpretación de la ninfa warburguiana que busca pensarla, por fuera de su habitual reducción a objeto de deseo erótico de la fantasía masculina, como hipóstasis del cuerpo femenino y figura de lo
8. El libro trabaja de modo exhaustivo las distintas fuentes del pensamiento warburguiano y, además de Nietzsche, estudia a Tylor, Burckhardt, Darwin, Vischer y Vignoli. Nietzsche y Burckhardt son, en opinión de Didi-Huberman, quienes inspiran a Warburg para pensar el aspecto "vital" de la supervivencia.
9. En la época de El nacimiento de la tragedia, Nietzsche compara el cristianismo con las fuerzas dionisíacas que dominan el mundo helénico apolíneo, elogia el evangelio de San Juan como continuidad de la voluntad sana y fuerte de Homero y de Sófocles, o, como recuerda Didi-Huberman, "evoca la supervivencia báquica en los bailes de San Vito, las tarantelas sicilianas y otras 'locuras colectivas' animadas de animismo y animalidad" (2009b: 137). También Agamben ha señalado, aunque al pasar, la influencia de Nietzsche en la concepción warburguiana del Pathosformel (2005: 138). 
10. Materialismo posthumano que, sostenido en la denuncia nietzscheanoadorniana-batailleana de la separación arbitraria (pero interesada) entre lo "alto" y lo "bajo", lo humano como un modelo de recognoscibilidad oposicional que sirve de criterio de valoración y jerarquización de todo lo existente, y que pugna por una redistribución de la agencia que ya no la atribuya exclusivamente a los hombres. No me detendré aquí en una definición de esta cantera de trabajo aún en elaboración, pero dejo señaladas algunas de sus fuentes filosóficas clásicas: Lyotard, 1998; Adorno: 1977: §§ 33-35; Bataille, 2003:56-64; Braidotti, 2013.

11. He trabajado en profundidad esta cuestión en Fleisner, 2014.

12. También Didi-Huberman considera a la ninfa y su desnudez desde el punto de vista del objeto del deseo y con el modelo venusiano. He discutido su interpretación en Fleisner, 2016.

13. Recordemos, a modo de ejemplo, los casos de Dafne, perseguida por Apolo y transformada en laurel o Aretusa, perseguida por Alfeo y transformada en fuente. inhumano que se desarrolla históricamente en el imaginario europeo occidental. Me refiero a la detallada lectura que propone Bogdana Paskaleva en su artículo sobre la desnudez de la ninfa (2016), de la cual tomaré algunos aspectos con el objetivo seguir pensando los posibles aportes de Warburg a un materialismo posthumano. ${ }^{10}$

En primer lugar, Paskaleva recupera el origen antiguo de la ninfa: una mujer joven, una deidad femenina menor conectada con una geografía particular (2016: 1). "Doncellas que pueblan la campiña, el bosque, y las aguas. Son los espíritus de los campos y de la Naturaleza en general, cuya fecundidad y gracia personifican", leemos en el diccionario de Grimal (1994: 380). Subrayemos las dos características: como la Koré, aunque es máxima indeterminación, la ninfa se declina en femenino y, acaso por ello, es (una en) el ambiente en el que existe. Continuum espíritu/materia, cultura/naturaleza, podríamos decir, siguiendo la genealogía renacimental de la ninfa que propone Agamben al recuperar el tratado de Paracelso sobre los Elementargeiste: hibridez de cuerpo y espíritu cuyo elemento es el agua, semejante en todo al hombre pero sin alma. Más que animales, menos que humanas, las ninfas son pura y absolutamente criaturas creadas por Dios en los elementos del mundo, sujetas a la muerte pero por siempre fuera de la economía de la salvación y la redención (Agamben: 2004: 62). Acaso criaturas vivientes antes de su encuentro con la ley, si apelamos a los binomios del prefacio de Categorías italianas, entendiendo aquí la ley como el encuentro erótico (obligado o deseado: máxima ambigüedad entre los modelos de Diana y de Venus) con varones (dioses u hombres, da igual) gracias al cual, según Paracelso (que elige a Venus), adquieren un alma (Agamben, 2004: 63). En el prefacio de aquella colección de ensayos Agamben dice haberse dedicado a pensar las oposiciones conceptuales: tragedia/comedia; ley/criatura y biografía/fábula. ${ }^{11}$ Es en este marco de oposición a la ley que podemos resignificar la caracterización de la ninfa como "pura criatura", y pensarla como un nombre para lo viviente no-ya/todavía-no humano: una existencia posthumana o inhumana con la plasticidad que le otorgan su fluidez, su indeterminación y su movilidad y que desborda todas las formas en las que se plasma. Criatura antes de la ley: ser inhumano inidentificable que, para ponerlo en relación con los otros pares de opuestos allí mencionados, abunda en las fábulas, no es reductible a la máscara moral de la tragedia (Agamben, 1996: 11-12) y expresa un carácter errático, nunca un destino (Agamben, 2015: 50). Situada en una zona de indistinción entre hombres, bestias y dioses, la ninfa es una figura única, parecida a todos ellos pero igualmente diferente. Un ser monstruoso que la ley busca apresar construyendo taxonomías jerarquizantes entre los seres para transformarla en vida humana, capturada, en su declinación paracelsiana, en un alma por obra del varón que hace de su cuerpo el receptáculo de un vástago que perpetre la especie. Por ello, creada a imagen del hombre, se vuelve su sombra, su imago y, como tal acompaña y desea para siempre (y es deseada por) aquello de lo que es imagen. Leído de esta manera, el modelo venusiano de Paracelso que Agamben adopta para reconducir a la ninfa a un objeto paradigmático de la pasión amorosa, ${ }^{12}$ repercute de manera especial en el modo en que se lee también las imágenes, toda vez que, como el filósofo italiano señala: "La historia de la ambigua relación entre los hombres y las ninfas es la historia de la difícil relación entre los hombres y sus imágenes" (Agamben, 2004: 64). Pero ¿Qué es una ninfa? ¿Qué son las imágenes? ¿Es la ninfa tan solo la encarnación del deseo erótico masculino? Hay al menos otros elementos que pueden tomarse en consideración, desde la declinación más antigua en el esquema de la persecución y la metamorfosis (Grimal, 1994: 381) asociada a Diana ${ }^{13}$, hasta la cuestión de la opacidad del cuerpo femenino devenido inhumano, que analiza Paskaleva. Pero además, ¿cómo hemos de caracterizar a las imágenes que se relacionan con los hombres?, ¿son inanimadas, puramente espirituales, representativas, ideales, abstractas, simbólicas? o ¿pueden, en las huellas warburguianas, ser portadoras de un pathos pero no ellas mismas pasivas, sino agenciales, materiales, expresiones de emotividades extrahumanas, sintomáticas? La interpretación de Paskaleva, tal vez sin proponérselo, nos ofrece algunas pistas al respecto. 
El segundo punto que quisiera rescatar de su lectura es la reconstrucción que propone del objeto científico warburguiano "ninfa" (¿carácter, imagen, Pathosformel?: "si mostraba in mille modi" -reza el poema de Lorenzo de Medici) a partir de la pregunta por su relación con el problema irresoluble que plantea el cuerpo femenino en general, por siempre in-humano (Paskaleva, 2016:4). El cuerpo de la ninfa, sugiere nuestra autora siguiendo a Kirchmayr, y, en particular, el asunto de su extraña desnudez, da cuenta ante todo de su indeterminabilidad, de la incerteza a la que arroja, de su carácter inconcebible, equívoco, impenetrable y opaco. No sabemos cuál es su esencia: Diana y Venus la encarnan por igual como archi-ninfas. Es, quizás, a la vez: lo in-para-femenino, lo in-para-corpóreo, que sirve de artilugio al antropocentrismo del Renacimiento que, en la lectura warburguiana, no se mide tanto con el teocentrismo, sino con la defiguración monstruosa y demoníaca de las formas culturales antiguas. Un modo de exploración, pero también una conjura de los frágiles límites de lo humano, la ninfa encarna un intento de transformar un monstruo arcaico en una divinidad que, no obstante, sigue siendo inhumana (Paskaleva, 2016: 5). Por ello, la ninfa warburguiana no se agota en una particular economía del deseo del varón/ humano, encarna la mayor intensidad del afecto (pathos), una agitación inmensa que expresa el grado más alto del estar poseído y que, al final de su vida, Warburg vinculará con la condición maníaca de la psique humana: experiencia efectiva de un afuera extra-humano, fórmula patética que se distribuye también en la materialidad de los objetos del mundo (cfr. Ludueña, 2017: 23-24).

La ninfa encarna de dos modos el movimiento: a través de su capacidad metamórfica y con su particular modo de la desnudez. Por un lado, las historias de metamorfosis (laurel, piedra, fuente, etc.) dan cuenta de su capacidad de fluctuación entre los reinos animal, vegetal y mineral, y de convertir así lo humano en otra cosa. La ninfa transformista parece, como decíamos, capaz de evadir las taxonomías impuestas a las criaturas en su encuentro con la ley.

Por otro lado, y este es el último punto que quisiera resaltar del análisis de Paskaleva, los límites de su cuerpo no son claros: lo que muestra su movimiento es una ambigua relación entre desnudez y bewegtes Beiwerk (paños ondeantes, cabellos movidos por el viento, elementos periféricos inanimados que dan la impresión de estar en movimiento), relación que se declina en una corporalidad femenina no capturable, siempre cambiante, que hace proliferar ilimitadamente los afectos (Paskaleva, 2016: 26-28). La ninfa está y no está desnuda: sus prendas, que la cubren solo en parte, des-cubren por acción del viento o de su postura dinámica, el contorno de su cuerpo. Una des-nudez incierta, fluida, hecha de vestidos que no funcionan como vestiduras, podríamos agregar. Prendas que lejos de transformarse en formas esenciales que determinan su lugar en una determinada jerarquía (como el ropaje eclesiástico, por ejemplo, cfr. Agamben, 2007: 215), son modos de la fluidez, parodias de toda desnudez esencial que muestran acaso, por contraposición, el proceso de desnudamiento por el que las criaturas son atrapadas en una vestidura (alma) para devenir humanas. Si, como señala Agamben, la desnudez no es un estado sino un evento, es porque es siempre la presuposición de una vestimenta o el resultado de su sustracción, es siempre una puesta al desnudo (Agamben, 2009: 96). La cuasi desnudez de las ninfas es, acaso, un juego en el disfraz de la desnudez que habilita la no adherencia a cualquier identidad (que pareciera es siempre nada más que humana), heraldo tal vez, de un posthumanismo por venir.

\section{Señalamiento engañoso}

En su libro sobre Warburg, Ludueña Romandini advierte contra la "tranquila etiqueta del posthumanismo que apenas sirve como señalamiento engañoso" porque lo que estará en juego será un acceso inaudito a la experiencia de un hipercosmismo 
absoluto (Ludueña, 2017: 77). Incluso tomando nota de esta advertencia, absolutamente pertinente si tenemos en cuenta algunas de las derivas de los debates actuales en torno al posthumanismo, y quizás porfiadamente, quisiera enmarcar mi trabajo aún bajo esa rúbrica. Porque lo que me interesa todavía, en un recorrido menos presuroso, acaso más perezoso, y sin dudas menos vanguardista, es pensar las huellas o las mediaciones que podrían eventualmente llevarnos al afuera que nos promete la genial disyuntología post-metafisica ludueñana. Es por ello que recupero no sin anacronismos de toda clase, y casi adueñándomelo en un gesto que quiere emular la tergiversación de términos como "queer" o "posmoderno", el término posthumano: para dar cuenta de la operatividad que aún tiene el concepto de humanidad en nuestras prácticas filosóficas, y la relación que guarda aún con el anti-humanismo del siglo pasado. Así, el posthumanismo declinado en una cierta versión materialista, y que yo practico de forma colectiva, acaso permitiría trazar coordenadas para pensar no solo lo extra-histórico como un continuum entre naturaleza e historia (y no ya como una esencia ideal), sino también las fuerzas materiales no teleológicamente organizadas que actúan y retroactúan en el planeta y fuera de él. En la época del devenir pétreo del hombre (Antropoceno), un pensamiento que asuma el componente inhumano de toda imagen y que afirme la aisthesis como elemento común de lo viviente podría eventualmente re-imaginar o re-encantar las relaciones múltiples que se dan dentro (y tal vez fuera) de la Tierra. 


\section{Bibliografía}

" Adorno, T. W. (1977). Terminología Filosófica Il (trad. J. Aguirre). Madrid: Taurus.

» Agamben, G. (2005). Aby Warburg e la scienza senza nome (1975/1984). En La potenza del pensiero (pp. 123-146). Vincenza: Neri Pozza.

"Agamben, G. (1996). Categorie italiane. Studi di poetica. Venezia: Marsilio.

»Agamben, G. (2005b). Genius. En Profanazioni (pp. 7-18). Roma: nottetempo.

"Agamben, G. (2007). Il Regno e la Gloria. Per una genealogia teologica dell'economia e del governo. Vicenza: Neri Pozza.

» Agamben, G. (2005). La potenza del pensiero. En La potenza del pensiero (pp. 173287). Vicenza: Neri Pozza.

» Agamben, G. (2004). Le pays au-delà-des images. En Image e mémoire (pp. 135141). París: Desclée de Brouwer.

» Agamben, G. (2015). Pulcinella ovvero Divertimento per li regazzi. Roma: nottetempo.

»Agamben, G. (2004b). Nymphae. Aut Aut, N 321-322: "Aby Warburg. La dialettica dell'immagine", pp. 53-67.

" Agamben, G. (2009). Nuditá. Roma: nottetempo.

"Agamben, G. (2008) Signatura rerum. Sul metodo. Torino: Bollati Boringhieri.

» Bataille, G. (2003). El bajo materialismo y la gnosis. En La conjuración sagrada. Ensayos 1929-1939 (trad. S. Mattoni). Buenos Aires: Adriana Hidalgo.

» Braidotti, R. (2015). Lo posthumano (trad. J. C. Gentile Vitale). Barcelona: Gedisa.

» Burucúa, J. E. (2003). Historia, arte, cultura. De Aby Warburg a Carlo Ginzburg. Buenos Aires: Fondo de Cultura Económica.

» Burucúa, J. E. (2011). Las tragedias y los desgarramientos de la Historia. Carta. Revista de pensamiento y debate del museo nacional centro de arte Reina Sofía, 2, 41- 43.

"Didi-Huberman, G. (2009). Ante la imagen. Pregunta formulada a los fines de una historia del arte (trad. F. Mailler). Murcia: Cendeac.

»Didi-Huberman, G. (2009b). La imagen superviviente. Historia del arte y tiempo de los fantasmas según Aby Warburg (trad. J. Calatrava). Madrid: Abada.

»Didi-Huberman, G. (2011). La lección de Warburg es que no existe saber sin sufrimiento (Entrevista con Georges Didi-Huberman, por M. D. Aguilera). Carta. Revista de pensamiento y debate del museo nacional centro de arte Reina Sofía, 2, 30-33.

»Didi-Huberman, G. (2017). Prefacio. Saber-movimiento (el hombre que le hablaba a las mariposas (1998). En Michaud, Ph-A., (2017). Aby Warburg y la imagen en movimiento (trad. V. Goldstein). Buenos Aires: Libros UNA.

»Fleisner, P. (2016). La trampa de Venus. Disponibilidad simbólica de los cuerpos y biopolítica de género. Generaciones, 5, Año 5, 43-57. Facultad de Psicología de la UBA. Buenos Aires: Eudeba.

" Fleisner, P. (2014). Vida criatural y comunidad de la nada. La política de indistinción entre hombres y animales en la filosofía de Giorgio Agamben. Revista Lati- 
noamericana de Estudios Críticos de Animalidad, Año I, vol №2.

» Foucault, M. (2004). Nietzsche, la genealogía y la historia (trad. J. Vázquez Pérez). Valencia: Pre-textos.

»Ghelardi, M. (2008). Il biólogo delle imagini. L' indice dei libri del mese, anno XXV, $\mathrm{N}^{\circ}$ 9, 24-25 [a propósito de la salida del libro: Warburg, A. (2007), La rinascita del paganesimo antico e altri scritti (a cura di M. Ghelardi). Torino: Aragno].

» Ginsburg, C. (2013). De Aby Warburg a Ernst H. Gombrich. Notas sobre un problema metodológico (1966). En Mitos, emblemas e indicios. Morfología e historia (pp. 51-125) (trad. V. Trentini, R. Lavalle y M. Padró). Buenos Aires: Prometeo.

» Grimal, P. (1994). Diccionario de mitología griega y romana (trad. F. Payarols). Barcelona: Paidós.

» Lyotard, J. F. (1998). Lo inhumano. Charlas sobre el tiempo. Buenos Aires: Manantial.

» Ludueña Romandini, F. (2009). Eternidad, espectralidad, ontología: hacia una estética trans-objetual. En A. Badiou, Pequeño manual de inestética (pp. 9-39) (trad. G. Molina, L. Vogelfang, J. L. Caputo y M. G. Burello). Buenos Aires: Prometeo.

" Ludueña Romandini, F. (2017). La ascensión de Atlas. Glosas sobre Aby Warburg. Buenos Aires: Miño y Dávila.

» Melandri, E. (2004). La línea e il circolo. Studio lógico-filosofico sull' analogía. Macerata: Quodlibet.

" Michaud, Ph-A. (2017). Aby Warburg y la imagen en movimiento (trad. V. Goldstein). Buenos Aires. Libros UNA.

» Nancy, J-L. (2007). La mirada del retrato (trad. I. Agoff). Buenos Aires: Amorrurtu.

» Nietzsche, F. (1994a). Ecce homo. Cómo se llega a ser lo que se es (trad. A. Sánchez Pascual). Madrid: Alianza.

» Nietzsche, F. (1994b). Cómo el «mundo verdadero» acabó convirtiéndose en una fábula. En Crepúsculo de los ídolos (trad. A. Sánchez Pacual). Madrid: Alianza.

» Nietzsche, F. (1980). (KSA) Sämliche Werke. Kritische Studienausgabe in 15 Bänden, (Eds.: G. Colli y M. Montinari). Berlín: Walter de Gruyer/Deutsche Taschenbuch Verlag.

»Panofsky, E. (1987). Introducción: La historia del arte en cuanto disciplina humanística. En El significado en las artes visuales (pp. 17-41) (trad. N. Acochea). Madrid: Alianza.

» Papapetros, S. (2016). Response to A Questionnaire on Materialism. 41 Responses. October. Art, Theory, Criticism, Politics (pp. 76-78). Cambridge: MIT Press.

" Paskaleva, B. (2016). The Nude Nymph: The Inhuman Object of Desire. La Rivista di Engramma on line, 135. Recuperado en: http://www.engramma.it/eOS2/index. php?id_articolo=2832 (última visita: 25/07/2016).

"Severi, C. (2003). Warburg anthropologue ou le déchiffrement d'une utopie. De la biologie des images a l'anthropologie de la mémoire. L'Homme. Revue français d'anthropologie, 165, 77-128.

»Vidarte, P. (2006). Derridalacan: contigüidades sintomáticas. Sobre el objeto pequeño j@cques. Conferencia pronunciada el 19 de octubre de 2006, en Buenos Aires, en el marco de las $V$ Jornadas internacionales Nietzsche y I Jornadas internacionales Derrida. Disponible en https://redaprenderycambiar.com.ar/derrida/ comentarios/derridalacan.htm (última visita: 24/07/2019). 
"Warburg, A. (1971). Burkhardt e Nietzsche (trad. it. R. Calasso). Adelphiana, número único, Milano. (Extracto de un cuaderno de 1927 llamado Bukhardt-Übungen).

"Warburg, A. (1996). La rinascita del paganesimo antico. Contributi alla storia della cultura (G. Bing ed./trad. it. E. Cantimori). Firenze: La nuova Italia.

"Wind, E. (1993). El concepto de Kulturwissenschaft en Warburg y su importancia para la estética (1930). En La elocuencia de los símbolos. Estudios sobre arte humanista (pp. 63-78) (trad. L. Millán). Madrid: Alianza. 
